\title{
EDITORIAL
}

\section{Online Teaching and Learning: Are We Doing It Right?}

The outbreak of COVID-19 pandemic in 2020 has caused a major transformation on the education system around the world. Educational institutions of all level, public and private were instructed to close their premises and resume the teaching and learning activities online. The closure of these educational institutions is unfortunately extended from time to time. This is considered as the safest option so far to break the infection chain which is believed to be "transmitted between people through respiratory droplets and contact routes" (WHO, 2020) and now believed to be airborne. In Malaysia, all curriculum and co-curricular activities in education involving mass gathering need to be temporarily halted to create social distance and ensure safety of all students and teachers (Yusri Muzamir and Amin Jali, 2020), (Abdul Halim Abdullah, 2020). As a result, Malaysian educators who were once heavily conventional has now started to utilize online communication platforms like Google Classroom, Zoom, Microsoft Teams, Telegrams, variety of online quizzes, materials and videos and so on. This drastic change has exposed educators and students to a number of challenges in adopting and adapting to the new norm in teaching and learning.

It is undeniable that ICT tools such as computers, projectors and so on are provided in the schools, but the use is restricted due to insufficient tools and Internet access, therefore not everyone gets to benefit them on frequent basis. The proof can be seen from the 1Bestarinet program, a virtual learning platform in schools introduced to enhance ICT usage among teachers and was not thoroughly adopted in most schools (Simin Ghavifekr, Tanusha Kunjappan, Logeswary Ramasamy, Annreetha Anthony, 2016). This scenario does not only happen in Malaysia but also in other parts of the world where ICT tools are considered as addons to classroom teachings, activities, projects, workshops and seminars (Sakilandeswari, 2020), (Johannes Konig, Daniela J. Jager-Biela, Nina Glutsch, 2020). In other words teachers are so used to traditional teaching and most of the time they are able to survive without the ICT tools. This is not to say that teachers do not acknowledge the value and benefits of ICT tools but the challenges they face during the usage outweigh the benefits. Similar situation is observed in the local universities as Prof Datuk Mohammad Shatar Sabran, the vice chancellor of Sultan Idris Education University (UPSI) mentioned, the online education system in the universities has not reach its optimum level even though Internet access is not a problem. Most people prefer face to face to virtual. In the West on the other hand they are more serious about using ICT tools in teaching and learning and the best part is they have built the system (Mediapermata, 2020).

Traditionally, distance education has been more successful at delivering content and less successful at providing interactivity and implementing the creative use of technology. Even the Internet, with all its advertised potential for interactivity and connectedness, has often been used simply to deliver print-based materials (e.g. downloadable PDFs) or other similar forms of noninteractive courseware. Streamed video on the Internet is commonly used to deliver course 
lectures recorded in classrooms (Renee Wallace, n.d). This situation is the result of educators having little or no knowledge and experience in utilizing the ICT tools in teaching and learning processes (Gold, 2001). He further contends that to become an effective online professional educator, one must engage in online learning to understand the way it works, what is lacking and how it should be done.

A successful online engagement unlike the traditional ones requires different sets of technical and pedagogical competencies to engage in effective teaching practices in online courses (Cyrs \& Conway, 1997). What the field of educational technology has postulated for over 30 years is that in order to encapsulate the potential of technology for increasing student learning, professional educators must have direct knowledge of, and experience with, the technology being used; technology experience (Renee, n.d). Professional educators must shift their instructional perspectives to be effective in an online environment. They do not have to abandon their teaching philosophies but rather, find innovative ways to demonstrate and utilize them in an online environment. Teaching online is very different from traditional classroom practice. Rather than being a sage on stage in a traditional classroom, an online professional educator is more like a guide on the side i.e. as a facilitator or coach to his/her students (Renee, n.d). Moderating is maintaining a constant flow of content-focused interaction between students. Strategies include encouraging students to participate in discussions as well as individual and group learning activities; keeping discussions focused on specific content; drawing out multiple perspectives; and summarizing and synthesizing the salient points of discussions.

Based on the elaborated literature above, it can be understood that a successful online teaching and learning requires engagement between educators and learners. In other words, the teaching and learning should be done interactively. Engagement creates active interactions and the role of educators is no longer teaching but facilitating to promote the engagement as much as possible. Only then the online teaching and learning reach its true meaning. However the present concern is the possibility to reach this level of effectiveness in a short period in times of "emergency". The sudden change requires sudden struggle. Associate Professor Tunku Badariah in Utusan Malaysia (2020) says "it's a huge responsibility requiring high efforts to reach high level of technical ability. The kind of successful and meaningful online teaching and learning however exist in the classroom where the educators have strong ICT background, knowledge, skill and experience.

Assoc. Prof. Dr. Sueraya Che Haron

Editor of IIUM Journal of Educational Studies (IJES),

Kulliyyah of Education,International Islamic University, Malaysia.

sueraya@iium.edu.my

June 20, 2021 